\title{
Weather station and annual temperature dynamics in the elevation gradient (spatial and temporal analysis of Chitwan-Annapurna, Nepal)
}

\begin{abstract}
This research was objectively done to assess gaps in distribution of weather stations, show temperature status and dynamics. Hence, primary data specifically minimum and maximum temperature from 1970 to 2015 was collected from 35 functional weather stations in Chitwan Annapurna Landscape (CHAL) of nineteen districts, Nepal. The map of the weather station was prepared. Moreover, linear regression, ANOVA and Duncan test were applied for statistical analysis. The result revealed that there was only one weather station above 3800 $\mathrm{m}$ elevation. The annual average, maximum and minimum temperatures below $200 \mathrm{~m}$ were $24.84 \pm 0.06,31.07 \pm 0.10$ and $18.61 \pm 0.73^{\circ} \mathrm{C}$ and the difference between these records was $12.46^{\circ} \mathrm{C}$. The highest differences in the temperature was recorded $14.56^{\circ} \mathrm{C}$ above 3800 $\mathrm{m}$ though the maximum and minimum temperatures were very low only $14.94 \pm 0.28$ and $0.38 \pm 0.20^{\circ} \mathrm{C}$ respectively. There was high correlation $\mathrm{r}^{2}$ with $0.955,0.922$ and 0.911 of average, maximum and minimum temperature against the elevation gradient. The annual increase in average temperature ranges between $0.02-0.06^{\circ} \mathrm{C}$. There was significance difference in annual increase in temperature according to elevation gradient. Moreover, there were eight statistically significant clusters of increasing temperature according to elevation gradient. The study guides the need of more weather stations.
\end{abstract}

Keywords: climate, weather, temperature, meteorological station, distribution, increase, altitude
Volume 5 Issue I - 2020

\author{
Ram Asheshwar Mandal \\ School of Environmental Science and Management, Pokhara \\ Univeristy, Nepal
}

Correspondence: Ram Asheshwar Mandal, School of Environmental Science and Management, Pokhara Univeristy, Nepal,Tel 984I450564,Email ram.manda@gmail.com

Received: January 07, 2020 | Published: February 14, 2020

\section{Introduction}

The weather predictions are very important for various purposes like agriculture, tourism and travel, energy, irrigation, drinking water supply, fishery, biodiversity conservation and other purposes ${ }^{1}$ particularly in mountainous country like Nepal. Climate Change is too fast in Nepal and disturbing the livelihood of the citizens in Nepal. ${ }^{2}$ The touristic activities specifically mountaineering, trekking and travel gets affected by weather in any country. The world is warming and it is not stop soon. ${ }^{3,4}$ The global surface temperature is projected to exceed by $1.5^{\circ} \mathrm{C}$ for RCP 4.5 , RCP 6.0 and RCP 8.5 (high confidence) by the end of the 21 st century (2081-2100) relative to $1850-1900 .^{5-7}$ The projection in temperature rise is alarming and it is expected to rise between 2.7 and $4.7^{\circ} \mathrm{C}$ by 2100 in Asia. ${ }^{8}$ The South Asian countries are projected to warm by $1^{\circ} \mathrm{C}$ (least scenario) by the end of the century. ${ }^{9}$ The mean annual temperature during the last 25 years period has increased by $1.5^{\circ} \mathrm{C}$ with an average annual increase of $0.06^{\circ} \mathrm{C}$ between 1982 and $2006 .{ }^{10}$

It is not easy to forecast accurate weather and climate, which suddenly invite huge human, social, physical and economical loss. ${ }^{11,12}$ There are several causes and risks associated to the prediction of weather and climate. ${ }^{13}$ Most important reason is unavailability of sufficient records of metrological data due to limit number of weather stations. ${ }^{14}$ On the other hand, the climate dynamic is the key issue which directly and indirectly relate to professions. ${ }^{15,16} \mathrm{~A}$ few scientists have explored the temperature dynamics of Nepal but the research associated with distribution of weather stations and temperature dynamics together particularly in Chitwan Annapurna Landscape (CHAL) area was not studied before. Hence, this research was objectively carried out to find the distribution gaps in weather station; assess the increase in mean temperature and reveal the relationship between temperature and altitude.

\section{Material and methods}

\section{Site selection}

Weather stations in Chitwan Annapurna Landscape (CHAL) area were selected for the study site which covers Manang, Mustang, Myagdi, Baglung, Gulmi, Arghakhanchi, Palpa, Syangja, Parbat, Kaski, Tanahu, Lamjung, Gorkha, Dhading, Nawalparasi, Chitwan, Makwanpur, Nuwakot and Rasuwa districts. Geographically, records of temperature of these districts represent Tarai (lowlands) to Himalayan regions. Altogether there were seventy five weather stations in CHAL area. However only 34 weather stations are regular and functional. The detail of these districts specifically altitude range, latitude; longitude and area are presented in Table 1.

Table I Description of districts of CHAL area

\begin{tabular}{lllll}
\hline Districts & Altitude $\mathbf{m}$ & No. of weather stations & Latitude $(\mathbf{N})$ in degree & Longitude $(E)$ in degree \\
\hline Manang & $1000-6400$ & $2(1)$ & 28.633 & 84 \\
Mustang & $2000-6400$ & $10(4)$ & 29.083 & 83.74 \\
Myagdi & $300-6400$ & $8(2)$ & 28.45 & 83.48 \\
\hline
\end{tabular}


Table continue

\begin{tabular}{lllll}
\hline Districts & Altitude $\mathbf{m}$ & No. of weather stations & Latitude $(\mathbf{N})$ in degree & Longitude (E) in degree \\
\hline Baglung & $300-5000$ & $4(I)$ & 28.27 & 83.59 \\
Gulmi & $300-3000$ & $3(I)$ & 28.09 & 83.29 \\
Arghakhanchi & $300-3000$ & $2(I)$ & 27.925 & 82.067 \\
Palpa & $300-2000$ & $3(2)$ & 27.868 & 83.55 \\
Syangja & $300-2000$ & $3(I)$ & 28.02 & 83.8 \\
Parbat & $300-4000$ & $3(I)$ & 28.01 & 80.693 \\
Kaski & $300-6400$ & $9(4)$ & 28.212 & 83.947 \\
Tanahu & $300-2000$ & $3(3)$ & 27.918 & 84.25 \\
Lamjung & $300-6400$ & $3(I)$ & 28.555 & 84.22 \\
Gorkha & $300-6401$ & $4(I)$ & 28.038 & 84.465 \\
Dhading & $300-5000$ & $2(I)$ & 27.975 & 84.433 \\
Nawalparasi & $200-2000$ & $5(3)$ & 27.533 & 83.668 \\
Chitwan & $200-2000$ & $3(2)$ & 27.583 & 84.5 \\
Makwanpur & $200-3000$ & $3(2)$ & 27.429 & 85.03 \\
Nuwakot & $300-5000$ & $3(2)$ & 28.17 & 83.917 \\
Rasuwa & $300-5500$ & $2(I)$ & 27.99 & 85.2 \\
\hline
\end{tabular}

Note Figure in parenthesis shows the number of weather stations having complete and regular temperature data

\section{Sampling and experimental design}

Temperature data were obtained from the Department of Hydrology and Meteorology, Government of Nepal (GoN) from 1970 to 2015 all 46 years of 34 weather stations. These weather stations were grouped based upon their distribution at interval of $200 \mathrm{~m}$ elevation. The graph of distribution of weather stations was prepared using Microsoft excel. The maps of weather stations were also prepared using geographical coordinates ( $\mathrm{X}$ and $\mathrm{Y}$ ) of location applying ArcGIS to show the spatial distribution. The text file of temperature data was converted into excel format to calculate the mean annual temperature of minimum, maximum and average temperature.

\section{Statistical comparison}

The Shapiro- Wilk normality test was done in R statistical software to examine the normality of the data. The data of average, minimum and maximum temperature showed the normal distribution (Kothari, 2004). Thus the parametric test specifically One-way ANOVA and multiple post hoc Duncan test were used to examine whether there was significant difference in mean temperature at $5 \%$ level of significance according to altitude. The summary statistics, linear regression model $1^{17,18}$ between altitude and temperature as well as increase in temperature between different periods were also calculated.

\section{Results and discussion}

\section{Distribution gaps in weather stations}

The regular and complete sets of temperature data are available only from 34 weather stations in Chitwan Annapurna Landscape area. Among them more than $55.88 \%$ i.e. 19 weather stations occur below $1200 \mathrm{~m}$ altitude; $14(41.17 \%)$ weather stations at the elevation range of 1200 to $3600 \mathrm{~m}$ and only one station i.e. $2.95 \%$ above $3600 \mathrm{~m}$ altitude (Figure 1\&Table 1). Some of the weather stations are not functioning well so the complete set of data is not available. The reason of incomplete set of metrological data may be due to irregularity in charging the solar batteries. The solar power system needs at least five hours sunlight each day. ${ }^{19}$ Another reason may be weather station is not regularly maintained ${ }^{20}$ due to lack of local technical experts.

The analysis reveals that a huge gap in distribution of weather stations in CHAL area according to the elevation band. The weather stations were nil in the elevation range of $600-800 \mathrm{~m}, 2800-3600 \mathrm{~m}$ and even only one weather station was at above $3800 \mathrm{~m}$. Moreover, the available record of temperature at elevation range of 1200-1400 $\mathrm{m}$ was not consistent. There are not any standard criteria and policies to maintain the distance between two weather stations. Generally weather stations are installed where there are easy accessibility and transportation to maintain the equipment and monitor the stations. Another reason is, the establishment of weather stations depends up on the objective of the institutions or project. However, the aspects, slope and hilly terrain have high influence on the climatic data. ${ }^{21}$ There are several weather stations in different parts of hilly region of India. There are 21 weather stations in Assam, 7 in Meghalaya, 1 in Sikkim and 7 in Arunachal Pradesh, ${ }^{22}$ though these numbers are also inadequate to understand the weather. The Himalayan Environmental Rhythms Observation and Evaluation System (HEROES) Project in Bhutan has been supporting a network of 23 weather stations out of that 20 stations were installed in schools, and 3 in remote mountain locations to relate the records of climate variable with the climate change issue. ${ }^{23}$ These are some examples of weather stations. However, it is realized that there are inadequate numbers of weather station in hilly areas in Nepal too to forecast the weather precisely (Figures 1\&2). 


\section{Distribution of weather stations according to elevation}

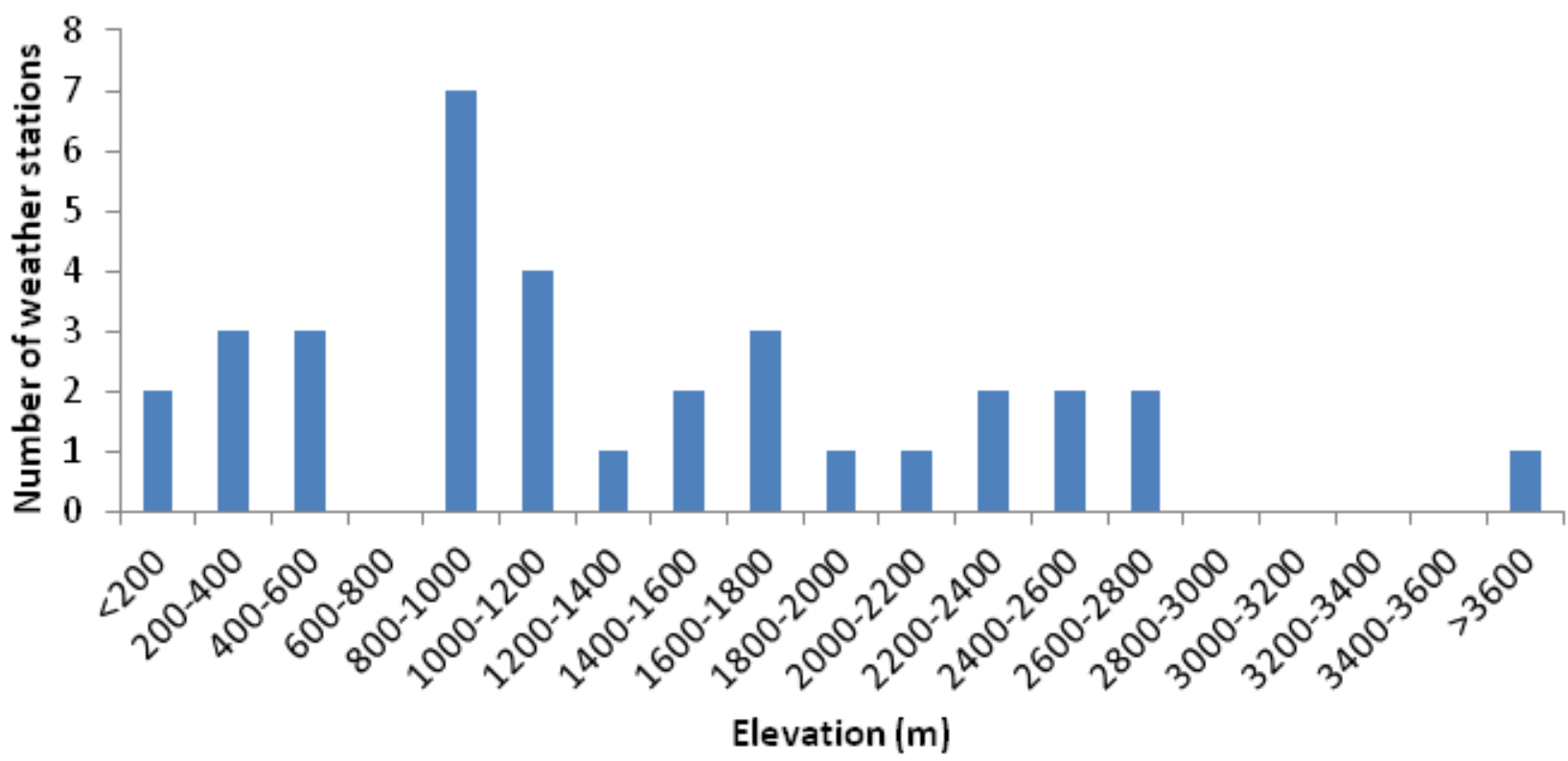

Figure I Number of weather stations according to elevation gradient altitude and distribution of weather stations.

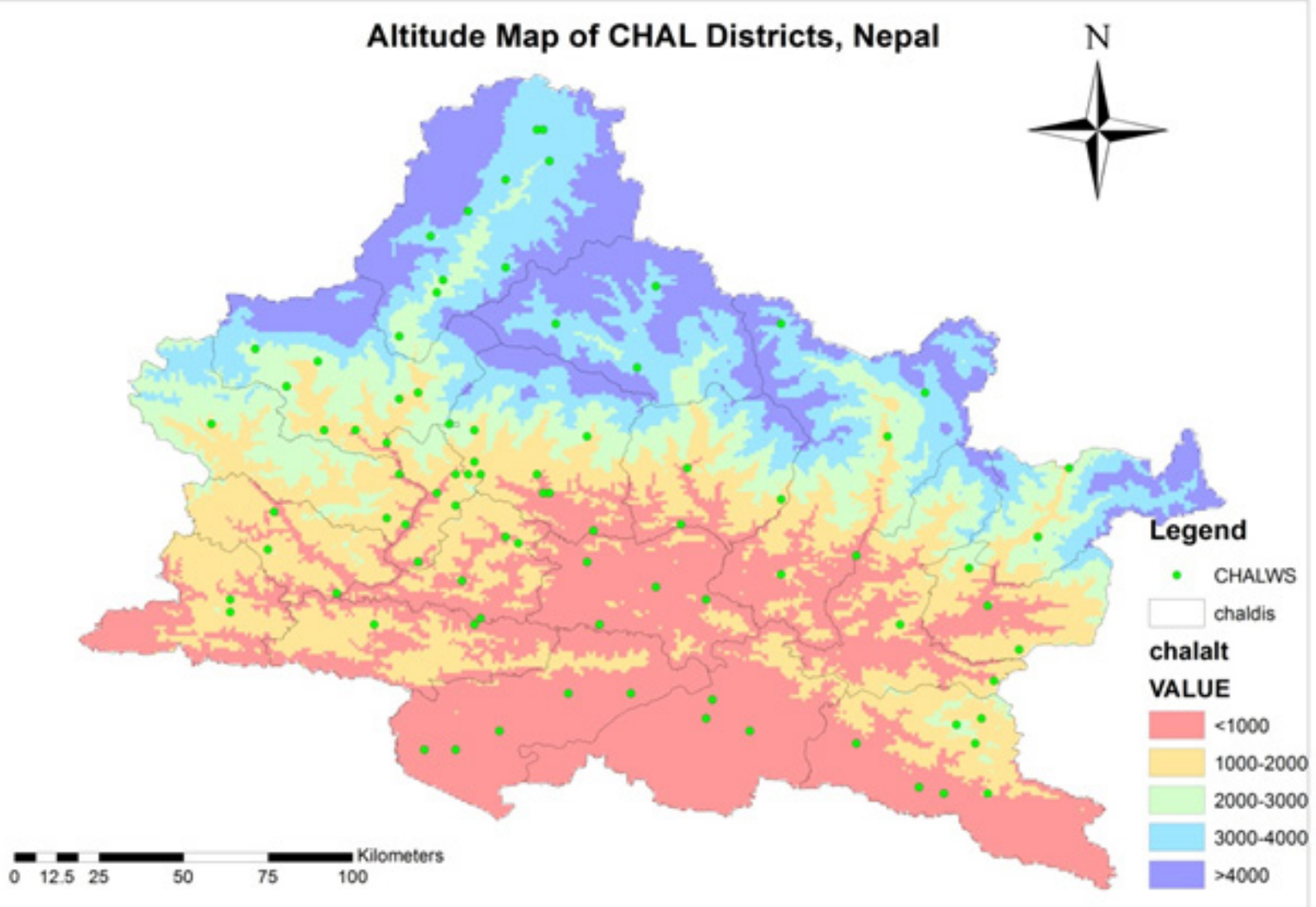

Figure 2 Altitudinal variation in CHAL. 
The altitude below $1000 \mathrm{~m}$ in CHAL covers about $11858.79 \mathrm{sq}$ $\mathrm{km}$ which is nearly $33.07 \%$ but the total number of weather station is 15 . The area of slope $>4000 \mathrm{~m}$ in CHAL cover nearly $8282.33 \mathrm{sq}$ $\mathrm{km}(23.10 \%)$ but there is no any weather station. Thus, the gaps are clearly indicated in weather station which is the problem of weather prediction in Nepal (Table 2).

Table 2 Altitude and area coverage

\begin{tabular}{llll}
\hline Altitude & Area Sq Km & Percentage & Remarks \\
\hline$<1000$ & 11858.79 & 33.07 \\
$1000-2000$ & 8277.78 & 23.08 \\
$2000-3000$ & 3802.65 & 10.6 \\
$3000-4000$ & 3639.46 & 10.15 \\
$>4000$ & 8282.33 & 23.1
\end{tabular}

\section{Temperature dynamics according to elevation}

The mean annual average, maximum and minimum temperatures were $24.84 \pm 0.06,31.07 \pm 0.10$ and $18.61 \pm 0.73^{\circ} \mathrm{C}$ below $200 \mathrm{~m}$ and the difference between mean maximum and minimum temperature was $12.46^{\circ} \mathrm{C}$. The highest differences in temperature was recorded $14.56^{\circ} \mathrm{C}$ above the $3800 \mathrm{~m}$ though the maximum and minimum temperatures were very low only $14.94 \pm 0.28$ and $0.38 \pm 0.20^{\circ} \mathrm{C}$ respectively. The lower minimum temperature below $6^{\circ} \mathrm{C}$ was recorded above $2400 \mathrm{~m}$ altitude. This research showed that the altitude has high influence on regional temperature which was supported by Jain and Kumar. ${ }^{24}$ The higher variation in minimum and maximum temperature, the higher influence is on climate change (Table 3 )..$^{25,26}$

\section{Spatial distribution of weather stations}

The spatial distribution of weather station showed that there was greater number of weather stations in western parts of CHAL in comparison to eastern area. Though altitudinal variation was very high in Gorkha district, there were only four weather stations. In case of Rasuwa district, there were only two weather stations which cannot represent the climate of western part. Air temperature observations at ground stations are essential but many high-altitude areas (greater than $4.000 \mathrm{~m}$ ) are still heavily under sampled (Figures 3-5) (Tables 4-6). ${ }^{27}$ The percentage coverage of aspect in CHAL area is varied. There are $31.81 \% \mathrm{SW}$ aspect in CHAL and it was followed by $26.81 \%$ SE aspect. The distribution of climatic variables of CHAL is also affected due to theses aspects. Obviously the temperature and rainfall are affected because of the hilly aspects.

Table 3 Summary statistics of maximum and minimum temperature $\left({ }^{\circ} \mathrm{C}\right)$ of $\mathrm{CHAL}$ area

\begin{tabular}{|c|c|c|c|c|c|c|}
\hline \multirow{2}{*}{$\begin{array}{l}\text { Altitude range } \\
\text { (m) }\end{array}$} & \multirow{2}{*}{$\begin{array}{l}\text { Elevation range } \\
(\mathrm{m})\end{array}$} & \multicolumn{4}{|c|}{ Temperature ${ }^{\circ} \mathrm{C}$ based on mean temperature } & \multirow{2}{*}{ Remark } \\
\hline & & Average & Maximum & Minimum & Difference (Max-Min) & \\
\hline$<200$ & 154 & $24.84 \pm 0.06$ & $31.07 \pm 0.10$ & $18.61 \pm 0.73$ & 12.46 & \\
\hline $200-400$ & $205-358$ & $24.22 \pm .08$ & $30.67 \pm .09$ & $17.77 \pm 0.11$ & 12.9 & \\
\hline $400-600$ & $460-500$ & $23.01 \pm .05$ & $29.20 \pm .07$ & $16.83 \pm .07$ & 12.37 & $\begin{array}{l}\text { Stations missing in } 600- \\
800 \&\end{array}$ \\
\hline $800-1000$ & $823-965$ & $21.12 \pm 0.06$ & $27.07 \pm 0.07$ & $15.17 \pm 0.06$ & 11.9 & $|200-| 400$ \\
\hline $1000-1200$ & $1003-1097$ & $20.97 \pm 0.08$ & $26.26 \pm 0.11$ & $15.68 \pm 0.09$ & 10.58 & $\mathrm{~m}$ altitude range \\
\hline $1400-1600$ & $1432-1530$ & $|7.68 \pm 0.1|$ & $22.87 \pm 0.16$ & $12.50 \pm 0.12$ & 10.37 & \\
\hline $1600-1800$ & $1740-1760$ & $15.87 \pm 0.07$ & $19.67 \pm 0.12$ & $12.07 \pm 0.06$ & 7.6 & \\
\hline $1800-2000$ & |900-1982 & 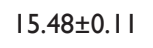 & $20.33 \pm 0.16$ & $10.63 \pm 0.17$ & 9.7 & \\
\hline $2000-2200$ & 2064 & $15.25 \pm 0.11$ & $19.87 \pm 0.08$ & $10.64 \pm 0.19$ & 9.23 & One station \\
\hline $2200-2400$ & $23 \mid 4-2384$ & $12.82 \pm 0.16$ & $18.02 \pm 0.14$ & $7.95 \pm 0.28$ & 10.07 & \\
\hline $2400-2600$ & $2530-2566$ & $11.32 \pm 0.10$ & $17.18 \pm 0.14$ & $5.46 \pm 0.13$ & 11.72 & \\
\hline $2600-2800$ & $2680-2744$ & $10.62 \pm 0.25$ & $16.68 \pm 0.23$ & $4.56 \pm 0.31$ & 12.12 & \\
\hline$>3800$ & 3870 & $7.80 \pm 0.28$ & $14.94 \pm 0.28$ & $0.38 \pm 0.20$ & 14.56 & One station \\
\hline
\end{tabular}

Note I There is inconsistency in weather station at 600-800, I200-I400, 2800-3600 and higher than 3900 m altitudes 


\section{Distribution of Weather Stations in CHAL area}

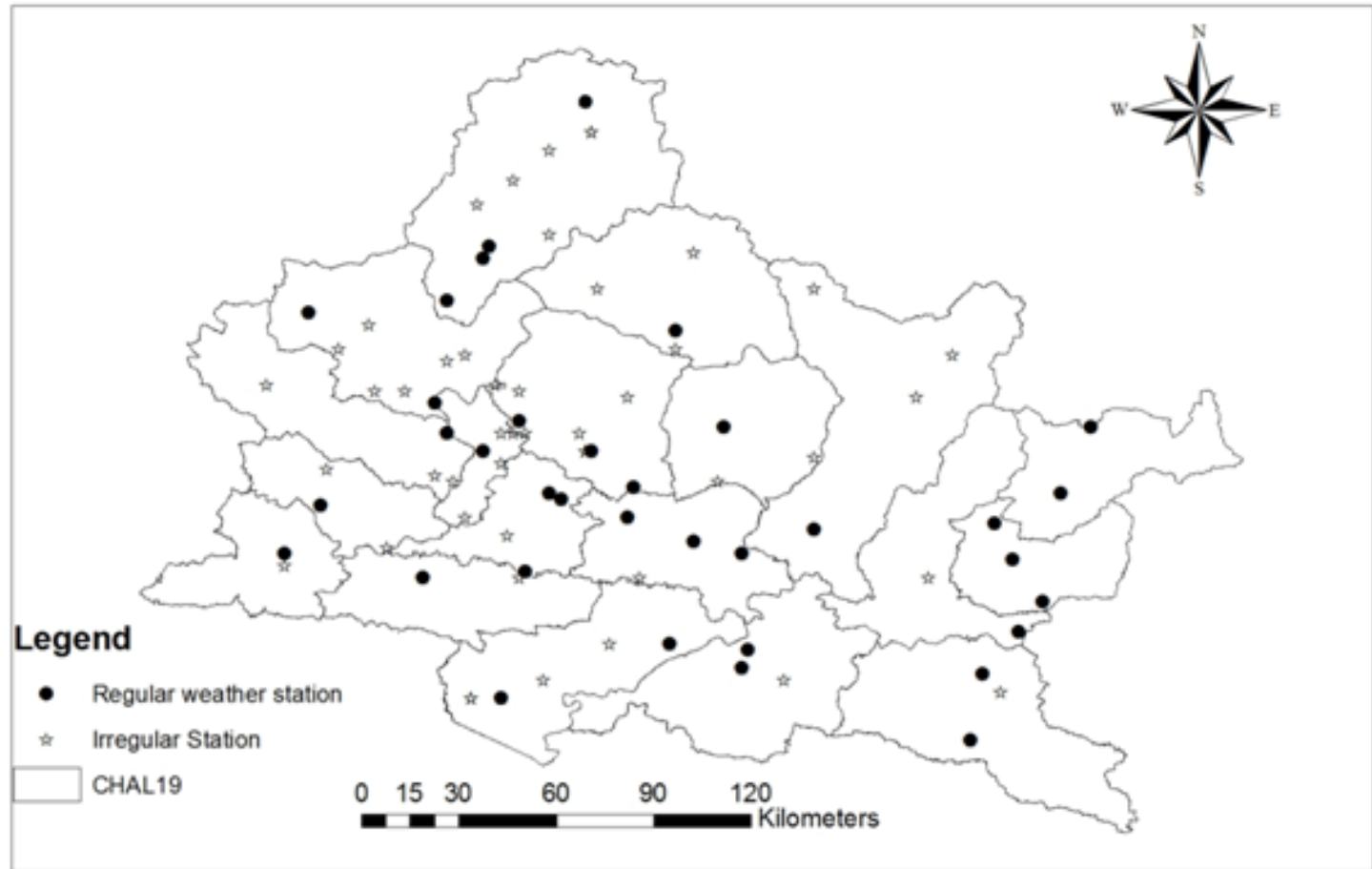

Figure 3 Spatial distribution of weather stations in CHAL area Nepal.

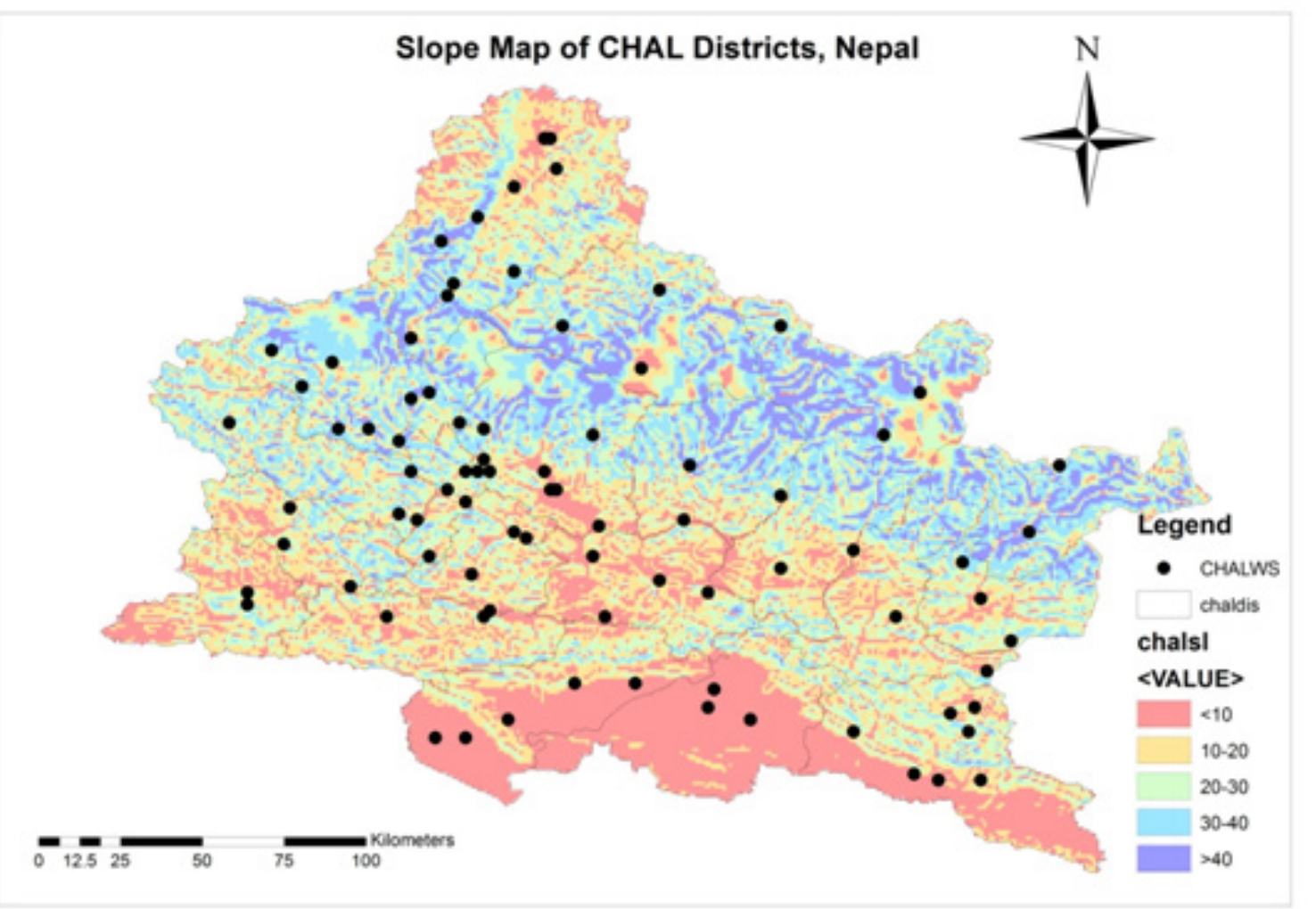

Figure 4 Slope dynamics in CHAL.

Citation: Mandal RA. Weather station and annual temperature dynamics in the elevation gradient (spatial and temporal analysis of Chitwan-Annapurna, Nepal). J His Arch \& Anthropol Sci. 2020;5(I):37-44. DOI: 10.15406/jhaas.2020.05.002I5 


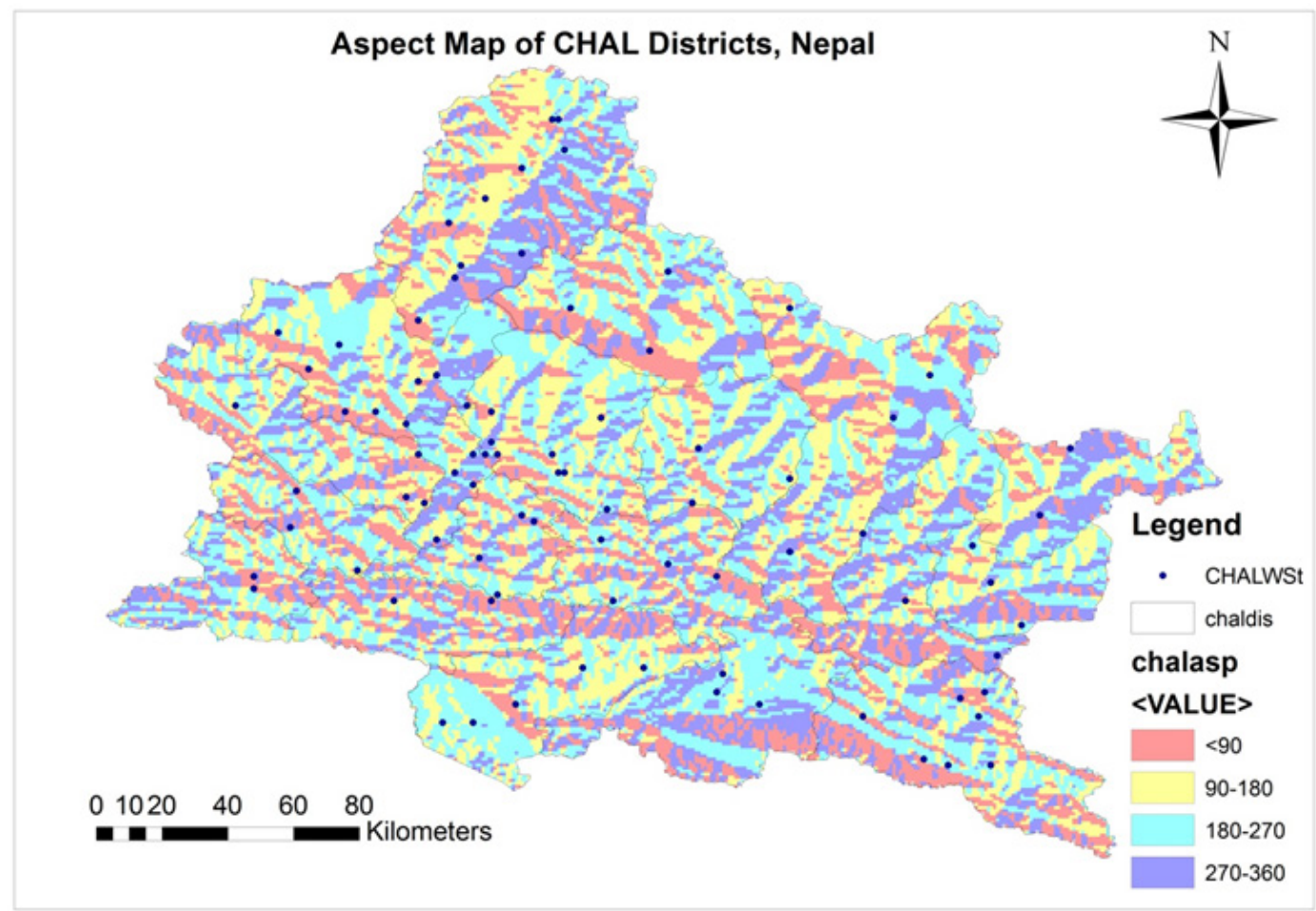

Figure 5 Aspect dynamics in CHAL area.

Table 4 The slope is another factor affecting the climatic variables in Nepal

\begin{tabular}{llll}
\hline Slope & Areas & Percentage & Remarks \\
\hline 0 to 10 & 16635.25 & 46.39 \\
10 to 20 & 13124.82 & 36.6 \\
20 to 30 & 5168.107 & 14.41 \\
30 to 40 & 878.9349 & 2.45 \\
$>40$ & 53.88979 & 0.15
\end{tabular}

Table 5 Aspect dynamics in CHAL area

\begin{tabular}{llll}
\hline Slope & Areas & Percentage & Remarks \\
\hline 0 to 10 & 16635.25 & 46.39 \\
10 to 20 & 13124.82 & 36.6 \\
20 to 30 & 5168.107 & 14.41 \\
30 to 40 & 878.9349 & 2.45 \\
$>40$ & 53.88979 & 0.15 \\
\hline
\end{tabular}

Table 6

\begin{tabular}{llll}
\hline Correlations & Regression equation & Coefficient of determination $\mathbf{R}^{2}$ & Remarks $^{2}$ \\
\hline Average Temperature VS Altitude & $\mathrm{Y}=0.005 \mathrm{X}+25.72$ & 0.955 \\
Maximum Temperature VS Altitude & $\mathrm{Y}=0.005 \mathrm{X}+31.95$ & 0.92 \\
Minimum Temperature VS Altitude & $\mathrm{Y}=0.005 \mathrm{X}+19.78$ & 0.911 \\
\hline
\end{tabular}

\section{Annual temperature dynamics and elevation gradient}

There was a strong relation between altitude and average annual temperature. The linear regression showed that the $\mathrm{R}^{2}$ value was 0.955 . The finding depicted that there was decrease in average temperature according to the elevation gradient from Tarai to Himalaya. This was justified by several studies like research done by Pepin and Seide ${ }^{28}$ and Oyler et al. ${ }^{29}$ Moreover, there is a rapid warming trend in high elevation zone $\mathrm{e}^{30,31}$ because of melting snow and ice result in lower surface albedo which contributes to further warming. ${ }^{32}$ The cooling is another key characteristic of high mountainous region in comparison to plain due to circulation of cold air. In fact, cold air pooling and local heating are happened due to combination of topography and synoptic condition. ${ }^{33,34}$ This may be one of the reliable reasons of rapid warming in high altitude. Similar results recorded for the relation between mean maximum annual temperature and elevation gradient having coefficient of determination $\left(\mathrm{R}^{2}\right)$ about 0.922 . Available records showed that there was very good relationship between minimum temperature and elevation gradient. The linear 
regression showed that $\mathrm{R}^{2}$ was 0.911 of these two variables. However, there was high variation in mean minimum temperature.

\section{Conclusion}

A big gap in occurrence of weather station at high elevations area especially above $2800-3600 \mathrm{~m}$ was noticed. The temperature rise was higher at high elevation and lower at low altitude. There was high correlation between temperature and elevation gradient. The present study reveals the need of weather stations above $2800 \mathrm{~m}$ and also emphasizes on the maintenance and monitoring weather stations regularly. ${ }^{35,36}$

\section{Acknowledgments}

None.

\section{Funding}

No financial support was available for this project.

\section{Conflicts of interest}

Author declares that there is no conflict of interest.

\section{References}

1. Parmesan C, Yohe G. A globally coherent fingerprint of climate change impacts across natural systems. Nature. 2003;42(1):37-42.

2. Dash SK, Jenamani RK, Kalsi SR, et al. Some Evidence of Climate Change in Twentieth-century India. Climatic Change. 2007;85(3-4):299-321.

3. Pounds JA, Fogden MPL, Campbell JH. Biological responses to climate change on a tropical mountain. Nature. 1999;398:611-615.

4. AAS. The science of climate change questions and answers. Australian Academy of Science. Canberra; 2015.

5. Le Treu H, Somerville R, Cubasch U, et al. Prather, Historical Overview of Climate Change. Climate Change: The Physical Science Basis. Contribution of Working Group I to the Fourth Assessment Report of the Intergovernmental Panel on Climate Change. USA: Cambridge University Press, Cambridge, United Kingdom and New York, NY; 2007.

6. Susie M, Franco G, Pittiglio S, et al. The Future Is Now: An Update on Climate Change Science Impacts and Response Options for California. California Energy Commission: PIER Energy Related Environmental Research Program. 2009;500(1):71.

7. Dell M, Jones BF, Olken BA. Temperature shocks and economic growth: Evidence from the last half century. American Economic Journal Macroeconomics. 2012;4(3):66-95.

8. IPCC. Climate Change 2014: Synthesis Report. In: Core Writing Team, RK Pachauri, LA Meyer, editors. Contribution of Working Groups I, II and III to the Fifth Assessment Report of the Intergovernmental Panel on Climate Change, Switzerland: IPCC, Geneva; 2014. 151 p.

9. Shrestha AB, Eriksson M. Climate Change in the Himalayas. Nepal: International Centre for Integrated Mountain Development, Kathmandu; 2009 .

10. Shrestha UB, Gautam S, Bawa KS. Widespread Climate Change in the Himalayas and Associated Changes in Local Ecosystems. PLoS One. 2012;7(5):36741.

11. Wigley T. The Climate Change Commitment. Science. 2005;307:1766-1769.
12. Slingo J, Palmer T. Uncertainty in weather and climate prediction Philosphical Translations of the Royal Society. 2011;369:4751-4767.

13. Moore FC, Diaz DB. Temperature impacts on economic growth warrant stringent mitigation policy. Nature Climate Change. 2015. p. 1-5.

14. DHM. Observed Climate Trend Analysis in the Districts and Physiographic Zones of Nepal (1971-2014). Nepal: Department of Hydrology and Meteorology, Kathmandu; 2017.

15. Pindyck RS. Uncertain outcomes and climate change policy. Journal of Environment Economics and Management. 2012;63:289-303.

16. Sharma G. Nepal plane crash in bad weather killed all 18 on Board. Kathmandu; 2014.

17. Shayib MA. Applied Statistics. The ebook Company: Book boon; 2013.

18. Singpurwalla D. A Handbook of Statistics: An Overview of Statistical Methods. 2017.

19. Jamil I, Jamil R, Jinquan Z, Ming L, et al. Application and Composition Observing System of Automatic Weather Station and Power Grid (PGMIS). Electrical and Electronics Engineering: An International Journal. 2013;2(4):31-45.

20. Lehner F, Stocker TF. From local perception to global perspective. Nature Climate Change. 2015;5(1:731-735.

21. Bojinski S. Status of meteorological network spacing requirements in WMO and GCOS guidance material. Switzerland: World Meteorological Organization, Geneva 2; 2010.

22. PIB. Automatic Weather Stations in North East India. Press Information Bureau: Climate Himalaya; 2011.

23. BFNPYC. Understanding the Climate Change in Bhutan. Thimpu Bhutan: Bhutan Foundation Nazhoen Pelri Youth Center; 2016.

24. Jain SK, Kumar V. Trend analysis of rainfall and temperature data for India. Current Science. 2012;102(1):37-49.

25. Easterling DR, Horton B, Jones PD, et al. Maximum and Minimum Temperature Trends for the Globe. Science. 1997;277(1):1-4.

26. Fiddes J, Endrizzi S, Gruber S. Large-area land surface simulations in heterogeneous terrain driven by global data sets: application to mountain permafrost, The Cryosphere. 2015;(1):411-426.

27. MRI, EDW, WG. Elevation-Dependent Warming In Mountain Regions Of The World. Mountain Research Initiative EDW Working Group. Nature Climate Change. 2015;5(1):424-430.

28. Pepin NC, Seidel DJ. A global comparison of surface and free-air temperatures at high elevations. Journal Geophysical Resource. 2005;110(1):1-15.

29. Oyler JW, Dobrowski SZ, Ballantyne AP, et al. Artificial amplification of warming trends across the mountains of the western United States. Geophysical Resource Letter. 2015;42(1):1-9.

30. Youa Q, Kang S, Pepind N, et al. Relationship between temperature trend magnitude, elevation and mean temperature in the Tibetan Plateau from homogenized surface stations and reanalysis data. Global and Planetary Change. 2010;71(1):124-133.

31. Rangwala I, Miller JR. Climate change in mountains: A review of elevation-dependent warming and its possible causes. Climate Change. 2012;114(3-4):527-547.

32. Chen B, WC Chao, X Liu. Enhanced climatic warming in the Tibetan plateau due to doubling $\mathrm{CO}_{2}$ : A model study. Climate Dynamics. 2003;20:401-413. 
33. Whiteman CD, Zhong S, Shaw WJ, et al. Cold pools in the Columbia Basin. Weather Forecasting. 2001;16:432-447.

34. ICIMOD. Sonw Cover Statistics- Nepal. E-bulletin: International Centre for Integrated Mountain Development (ICIMOD); Nepal. 2013.
35. Kothari CR. Research Methodology Methods and Techniques. India: College of Commerce, University of Rajsthan, Jaipur; 2004.

36. Shrestha AB, Wake CP. Maximum temperature trends in the Himalaya and its vicinity: An analysis based on temperature records from Nepal for the period 1971-94. Journal of Climate.1999;12:2775-2787. 